\title{
Pengaruh Strategi Pembelajaran Tipe Two Stay Two Stray Berbasis WhatsApp Terhadap Hasil Belajar Materi Zat Aditif dan Adiktif di SMP Negeri 4 Bitung
}

\author{
Gladys Sisca Pusung ${ }^{1 *}$, Herry Maurits Sumampouw ${ }^{2}$ \\ 1,2 Jurusan Pendidikan IPA, FMIPA, Universitas Negeri Manado \\ *e-mail: gpusung26@gmail.com
}

\begin{abstract}
Abstrak. Hasil belajar siswa di SMP N 4 Bitung masih di bawah KKM, hal ini terjadi karena belum digunakan strategi pembelajaran yang efektif dan efisien. Strategi pembelajaran harus selalu dikembangkan untuk menarik minat belajar siswa. Strategi pembelajaran yang dapat digunakan adalah Tipe Two Stay Two Stray (TSTS) berbasis WhatsApp. Penelitian ini bertujuan untuk membahas pengaruh strategi pembelajaran tipe TSTS berbasis WhatsApp terhadap materi hasil belajar zat aditif dan adiktif. Penelitian ini merupakan jenis eksperimen semu dengan menggunakan rancangan nonequivalent control group design. Populasi dalam penelitian ini adalah seluruh siswa kelas VIII di SMP N 4 Bitung yang berjumlah 56 siswa sedangkan sampel yang digunakan untuk kelas VIII A sebagai kelas eksperimen berjumlah 28 siswa dan kelas VIII B sebagai kelas kontrol berjumlah 26 siswa. Pengambilan data dilakukan dengan memberikan pretest sebelum perlakuan dan posttest sesudah perlakuan. Hasil penelitian yang diperoleh berupa selisih nilai rata-rata hasil pretest dan posttest pada kelas eksperimen adalah 43,21 sedangkan untuk kelas kontrol 34,81. Setelah diuji statistik melalui uji-t diperoleh $t_{\text {hitung }}=6,10>t_{\text {tabel }}=2,007$. Dengan demikian uji hipotesis diterima bahwa terdapat pengaruh strategi pembelajaran tipe TSTS berbasis WhatsApp terhadap hasil belajar materi zat aditif dan adiktif SMP N 4 Bitung.
\end{abstract}

Kata kunci: two stay two stray, whatsapp, hasil belajar, zat aditif dan adiktif

\begin{abstract}
Student learning outcomes at SMP N 4 Bitung are still below the KKM, this happens because effective and efficient learning strategies have not been used. Learning strategies must always be developed to attract students' interest in learning. The learning strategy that can be used is the WhatsApp based Two Stay Two Stray (TSTS) type. This study aims to discuss the effect of the WhatsApp based TSTS-type learning strategy on the learning outcomes of additive and addictive substances. This research is a quasiexperimental type using a nonequivalent control group design. The population in this study were all students of class VIII at SMP N 4 Bitung totaling 56 students while the sample used for class VIII $A$ as the experimental class was 28 students and class VIII B as the control class was 26 students. Data collection was done by giving pretest before treatment and posttest after treatment. The results obtained in the form of the difference in the average value of the pretest and posttest results in the experimental class is 43.21 while for the control class it is 34.81. After being tested statistically through the t-test, it was obtained that $t_{\text {count }}=6.10>t_{\text {table }}=2.007$. Thus, the hypothesis test is accepted that there is an influence of the WhatsApp based TSTS type learning strategy on the learning outcomes of additive and addictive materials at SMP N 4 Bitung.
\end{abstract}

Keywords: two stay two stray, whatsapp, learning outcomes, additives and addictive 


\section{PENDAHULUAN}

Pendidikan bertujuan untuk mempersiapkan generasi muda sebagai penerus bangsa yang mampu menghadapi perkembangan ilmu pengetahuan dan teknologi. Pemerintah dari tahun ke tahun selalu menyoroti dunia pendidikan bahkan selalu mengadakan perubahan perbaikan kurikulum, dimaksudkan agar pendidikan di Indonesia ini semakin menuju kearah yang lebih baik serta menciptakan manusia-manusia yang berkarakter dan kecerdasan yang tinggi karena kemajuan bangsa ditentukan pada generasi-generasi yang hebat. Salah satu upaya pemerintah untuk memperbaiki dunia pendidikan adalah merumuskan kurikulum 2013 berbasis karakter, di mana kurikulum 2013 tersebut menuntut siswa lebih aktif, kreatif, inovatif, kerjasama dan mandiri dalam melaksanakan pembelajaran (Sudjana, 2009).

Saat ini negara-negara di dunia sedang dilanda pandemic Covid-19. Berkaitan dengan adanya wabah Covid-19 pada awal tahun 2020, pemerintah kemudian mengeluarkan himbauan untuk melakukan kegiatan pembelajaran dari rumah. Saat ini, metode pembelajaran di berbagai institusi pendidikan tidak selalu harus diselenggarakan di melalui tatap muka. Terdapat model pembelajaran lain yang bisa digunakan oleh tenaga pengajar sebagai media penyampaian ilmu pengetahuan, yaitu pembelajaran daring dan pembelajaran campuran yang merupakan kombinasi dari dua metode pembelajaran yaitu tatap muka yang disebut luring dan pembelajaran daring (Zhafira, Ertika, \& Chairiyaton, 2020).

Hal ini dilakukan demi memutus rantai penyebaran virus dan menjaga keamanan serta keselamatan peserta didik dan tenaga pendidik. Dengan adanya himbauan tersebut maka proses pembelajaran pun dilakukan dari rumah dengan memanfaatkan teknologi dan media internet. Salah satu pembelajaran dengan menggunakan teknologi adalah pembelajaran elektronik atau dikenal dengan e-learning (Wowor, Tumewu, \& Rogahang, 2020).
Semua sekolah yang sebelumnya melakukan pembelajaran tatap muka di sekolah masing-masing, kini harus mengadaptasi model pembelajaran $e$ learning atau yang biasa disebut pembelajaran daring atau online dan juga pembelajaran luring atau yang disebut offline namun memerlukan tatap muka. Maka dengan adanya kehidupan new normal di era pandemi ini guru-guru diizinkan untuk mengunjugi siswa ke rumah tetapi dengan mematuhi protokol kesehatan. Pembelajaran luring dilakukan karena tidak semua tempat bisa mengaplikasikan pembelajaran online atau secara daring. Pembelajaran luring memberikan manfaat bagi kedua belah pihak, baik guru maupun siswa. Bagi siswa, pembelajaran luring muncul sebagai salah satu metode alternatif belajar yang efektif dan mereka juga tidak hadir di kelas melainkan bisa dilakukan di rumah, jadi guru yang akan mengunjungi siswa ke rumah. Sedangkan untuk pembelajaran dengan WhatsApp beberapa hal yang dilakukan oleh guru adalah ketika pembelajaran luring selesai guru kemudian memberikan penjelasan materi lagi dengan mengirim ke grup WhatsApp kelas. Guru dapat mengirim pembahasan dengan lengkap melalui WhatsApp serta memberikan soal untuk dijawab oleh siswa.

Penelitian ini dilaksanakan di SMP Negeri 4 Bitung awalnya pembelajaran dilakukan di kelas, kemudian setelah adanya pandemi ini maka pembelajaran dilakukan luar terbuka maupun di rumah berdasarkan proses pembelajaran luring. Hasil belajar siswa berdasarkan nilai ulangan pada mata pelajaran IPA kelas VIII mengalami masalah, hal ini terjadi karena siswa tidak mencapai Kriteria Ketuntasan Minimal (KKM) yang ditetapkan oleh sekolah. Pada mata pelajaran Ilmu Pengetahuan Alam (IPA) siswa harus mencapai nilai 70 dikatakan tuntas. Siswa yang belum tuntas masih mencapai nilai dibawah 70 .

Masalah hasil belajar terjadi karena belum digunakan strategi pembelajaran yang efektif dan efisien. Strategi pembelajaran harus selalu di kembangkan untuk menarik minat 
belajar siswa. Rendahnya hasil belajar siswa juga di sebabkan oleh metode pembelajaran yang digunakan masih bersifat konvensional seperti ceramah sehingga membuat guru cenderung lebih berperan aktif dari siswa. Untuk mendapatkan cara belajar menyenangkan dan menarik minat siswa dapat menggunakan metode pembelajaran yang berpusat pada siswa dan mengutamakan siswa lebih aktif di kelas dibandingkan dengan guru.

Pembelajaran lebih terpusat pada guru, maka siswa hanya akan mendapatakan hafalan bukanlah pemahaman yang didapatkan dalam pembelajaran. Dengan pembelajaran terpusat pada siswa, siswa akan menemukan pemahamannya sendiri dengan berbagai strategi yang mereka ciptakan. Untuk mengatasi permasalahan tersebut diperlukan strategi pembelajaran yang tepat agar siswa tidak merasa jenuh dan bisa membangkitkan keberanian siswa untuk tampil didepan kelas. (Sanjaya, 2012).

Strategi pembelajaran adalah cara yang dipergunakan untuk mencapai tujuan pembelajaran yang telah ditetapkan (Hamruni, 2012). Salah satu keterampilan yang harus dimiliki oleh seorang guru dalam pembelajaran adalah keterampilan memilih strategi, karena strategi yang akan digunakan oleh guru dalam proses pembelajaran akan sangat menentukan berhasil tidaknya pembelajaran. Strategi pembelajaran yang dapat digunakan adalah tipe TSTS berbasis WhatsApp. Strategi ini memberikan kesempatan kepada kelompok membagikan hasil dan informasi kepada kelompok lain melalui grup di WhatsApp. Seperti diketahui ragam media, WhatsApp dan beberapa media sosial yang lain sudah memudahkan proses pembelajaran, jadi walaupun nanti siswa ada yang berhalangan hadir tidak akan ketinggalan pelajaran karena pembelajaran TSTS berbasis WhatsApp sangat mudah untuk dilakukan.

Tujuan penelitian ini adalah untuk membahas pengaruh strategi pembelajaran tipe TSTS berbasis
WhatsApp terhadap hasil belajar materi zat aditif dan adiktif di SMP Negeri 4 Bitung.

\section{METODE PENELITIAN}

Penelitian ini dilaksanakan di kelas VIII SMP Negeri 4 Bitung dan waktu penelitian ini dilaksanakan pada bulan oktober semester ganjil tahun ajaran 2020/2021.

Metode penelitian yang digunakan adalah eksperimen semu. Data diambil melalui nilai pretest dan posttest kelas VIII SMP Negeri 4 Bitung.

Rancangan yang digunakan adalah nonequivalent control group design yang merupakan bentuk metode penelitian eksperimen semu (quasi experimental) yaitu desain kuasi eksperimen dengan melibatkan perbedaan pretest posttest antara kelas eksperimen dan kelas kontrol yang tidak dipilih secara random (acak). Penelitian ini melibatkan dua kelas, yaitu kelas eksperimen dan kelas kontrol. Kelas eksperimen dan kelas kontrol mendapatkan perlakuan pembelajaran yang sama dari segi tujuan, isi, bahan pembelajaran dan waktu belajar. Desain model penelitian dapat dilihat pada Tabel 1.

Tabel 1. Desain model penelitian

\begin{tabular}{llll}
\hline Kelompok & Pretest & Perlakuan & Posttest \\
\hline $\begin{array}{l}\text { Eksperimen } \\
\text { (R) }\end{array}$ & $\mathrm{O}_{1}$ & $\mathrm{X}_{1}$ & $\mathrm{O}_{2}$ \\
$\begin{array}{l}\text { Kontrol } \\
(\mathrm{R})\end{array}$ & $\mathrm{O}_{1}$ & $\mathrm{X}_{2}$ & $\mathrm{O}_{2}$ \\
\hline
\end{tabular}

Tabel 1 menunjukkan $\mathrm{X}_{1}$ adalah pelaksanaan pembelajaran dengan menggunakan strategi two stay two stray, $\mathrm{X}_{2}$ adalah pelaksanaan pembelajaran dengan menggunakan metode ceramah/ konvensional, $0_{1}$ adalah tes awal kelas ekperimen dan kelas kontrol, dan $\mathrm{O}_{2}$ adalah tes akhir kelas ekprimen dan kelas kontrol. Rancangan ini digunakan dua kelompok sampel penelitian yaitu kelas VIII A sebagai kelas eksperimen dan kelas VIII B sebagai kelas kontrol di SMP Negeri 4 Bitung.

Instrumen yang digunakan sebagai alat untuk memperoleh data yang diperlukan oleh peneliti dalam kegiatan 
penelitian yaitu observasi dan tes. Tes yang digunakan yaitu tes essay, sebelum instrumen hasil belajar tersebut digunakan terlebih dahulu sudah dilakukan uji validitas.

Data hasil belajar siswa dikumpulkan dengan memberikan tes sebelum dan tes sesudah pembelajaran selesai pada materi IPA, sebelum tes tersebut diberikan terlebih dahulu akan diuji validitas dan reliabilitas. Selanjutnya data diuji dengan prasyarat analisis yang terdiri dari uji normalitas dan homogenitas. Tahap terakhir adalah uji hipotesis.

\section{HASIL DAN PEMBAHASAN}

Penelitian ini bertujuan untuk mengetahui pengaruh penggunaan strategi pembelajaras TSTS berbasis WhatsApp terhadap peningkatan hasil belajar siswa kelas VIII SMP Negeri 4 Bitung pada sub materi zat aditif dan adiktif. Data hasil penelitian ini diambil dari dua kelas di SMP Negeri 4 Bitung yaitu kelas VIII A sebagai kelas eksperimen yang berjumlah 28 orang dan kelas VIII B sebagai kelas kontrol yang berjumlah 26 orang. Data yang diambil adalah hasil belajar siswa pada sub materi zat aditif dan adiktif yang diambil dari posttest. Kegiatan pertama yang dilakukan adalah melakukan tes awal (pretest) terhadap masing-masing kelas. Tes awal dilakukan untuk mengetahui kemampuan awal siswa sebelum dilakukan perlakuan. Setelah dilakukan perlakuan selanjutnya di beri tes akhir (posttest) kepada masing-masing kelas untuk mengetahui apakah ada peningkatan hasil belajar siswa setelah diterapkan ketercapaian penguasaan materi zat aditif dan adiktif pada siswa kelas VIII A dan Kelas VIII B dilihat pada saat postest.
Tabel 2. Rakapitulasi skor hasil belajar kelas eksperimen

\begin{tabular}{llll}
\hline Statistik & Pretest & Posttest & Selisih \\
\hline Rata-rata & 35,71 & 78,92 & 43,21 \\
$\begin{array}{l}\text { Skor } \\
\text { maksimum }\end{array}$ & 15 & 70 & 55 \\
$\begin{array}{l}\text { Skor } \\
\text { minimum }\end{array}$ & 60 & 85 & 25 \\
$\begin{array}{l}\text { Standar } \\
\text { deviasi }\end{array}$ & 14,95 & 6,13 & 8,81 \\
Varians & 223,54 & 37,69 & 185,84 \\
\hline
\end{tabular}

Pada Tabel 2 menunjukkan bahwa hasil pretest dan posttest pada kelas eksperimen dengan nilai rata-rata pretest 35,71 dan posttest 78,92 dengan standar deviasi pretest 14.95 dan posttes 6,13 dengan varians pretest 223,54 dan posttest 37.69 .

Tabel 3. Rakapitulasi skor hasil belajar kelas kontrol

\begin{tabular}{llll}
\hline Statistik & Pretest & Posttest & Selisih \\
\hline Rata-rata & 30,58 & 65,38 & 34,81 \\
$\begin{array}{l}\text { Skor } \\
\text { maksimum }\end{array}$ & 15 & 50 & 35 \\
$\begin{array}{l}\text { Skor } \\
\text { minimum }\end{array}$ & 55 & 80 & 25 \\
$\begin{array}{l}\text { Standar } \\
\text { deviasi }\end{array}$ & 13,58 & 7,33 & 6,25 \\
Varians & 184,65 & 53,84 & 130,80 \\
\hline
\end{tabular}

Pada Tabel 3 menunjukkan bahwa nilai rata-rata pada kelompok kontrol untuk pretest 30,58 dan posttest 65,38 dengan standar deviasi pretest 13.58 dan posttest 7.33 dengan varians pretest 184.65 dan posttest 53.84 .

Berdasarkan hasil yang diperoleh maka hipotesis dari hasil pengujian dengan melakukan uji-t diperoleh thitung $=$ 6,104 dan $t_{\text {tabel }}=2,007$ dengan kriteria pengujian jika thitung $>$ tabel maka $\mathrm{H}_{0}$ ditolak dan $\mathrm{H}_{\mathrm{a}}$ diterima.

Strategi pembelajaran TSTS berbasis WhatsApp berpengaruh terhadap hasil belajar materi zat aditif dan adiktif. Hal ini berarti terdapat terbedaan hasil belajar dimana hasil belajar siswa yang menggunakan strategi pembelajaran TSTS berbasis WhatsApp lebih tinggi dibandingkan hasil belajar kelas yang menggunakan pembelajaran konvensional. Ini dikarenakan dengan menggunakan strategi pembelajaran 
TSTS berbasis WhatsApp siswa cenderung lebih aktif serta dapat berkerja sama dengan kelompok, bahkan setelah tiba di rumah siswa di berikan materi kembali oleh guru melalui WhatsApp sehingga materi terus diingat oleh siswa. Berbeda dengan metode konvensional guru hanya menjelaskan materi melalui ceramah yang menjadikan siswa bosan mudah lupa dengan materi karena tidak merasakan diskusi dan membahasa pelajaran secara mandiri. Pembelajaran strategi TSTS berbasis WhatsApp sangat efektif dalam meningkatkan hasil belajar siswa, hal ini dapat dilihat dari rata-rata hasil belajar TSTS berbasis WhatsApp kelas eksperimen yaitu 43,21 lebih tinggi dari rata-rata hasil belajar kelas kontrol dengan menggunakan pembelajaran konvensional yaitu 34,81 .

Penggunaan strategi pembelajaran TSTS berbasis WhatsApp saat ini perlu diupayakan untuk dilakukan terutama pada pokok-pokok bahasan tertentu. Apalagi saat ini dunia pendidikan adalah salah satu yang terkena dampak pandemic Covid-19 sehingga tidak memungkinkan untuk belajar secara langsung disekolah. Namun peneliti mengembangkan strategi belajar saat situasi pandemic seperti sekarang ini yaitu belajar secara kelompok dengan cara luring atau luar jaringan. Peneliti dapat mengunjungi siswa ke rumah maupun ke sekolah untuk belajar secara luring. Tidak hanya itu yang peneliti lakukan juga adalah dengan belajar berbasis WhatsApp setelah peneliti selesai melakukan proses belajar luring, agar siswa lebih mendalami peneliti kembali membahasa materi zat aditif dan adikitif melalai WhatsApp siswa-siswa yang tentu saja sudah sepengatahuan orang tua dan guru kelas VIII di SMP Negeri 4 Bitung.

Penelitian ini sejalan dengan penelitian yang dilakukan oleh Asriyanti, Ernawati, \& Rahim (2020) yang menunjukkan bahwa terdapat pengaruh signifikan penggunaan model pembelajaran TSTS dengan media WhatsApp pada materi bangun datar segiempat terhadap prestasi belajar matematika siswa kelas VII.
Sejalan juga dengan penelitian yang dilakukan oleh Lestari, Tangkas, \& Sabang (2014) yang menunjukkan hasil bahwa terdapat perbedaan hasil belajar siswa yang menggunakan model two stay two stray dan berpengaruh secara siginifikan. Selanjutnya, penelitian yang dilakukan oleh Febriyanti, Jampel, \& Syahruddin, (2014) menunjukkan bahwa terdapat perbedaan yang signifikan hasil belajar matematika antara siswa yang mengikuti model pembelajaran two stay two stray berbantuan media konkret dengan siswa yang mengikuti pembelajaran konvensional.

Lebih lanjut, penelitian sebelumnya yang dilakukan oleh Hendrawan, Pudjawan, \& Wibawa (2017) menunjukkan hasil bahwa terjadi perbedaan antara hasil belajar IPA antara siswa yang dibelajarakan dengan model pembelajaran TSTS dan siswa yang dibelajarkan dengan model pembelajaran konvensional. Penelitian lainnya oleh Wahyuni \& Munthe (2014) menunjukkan bahwa model stay two stray berpengaruh terhadap hasil belajar siswa pada materi listrik dinamis pada siswa SMA. Penelitian yang dilakukan oleh Moro (2016) juga mendukung hasil penelitian ini, dimana penelitiannya menunjukkan bahwa penggunaan WhatsApp dapat berpengaruh terhadap prestasi belajar siswa.

\section{KESIMPULAN}

Berdasarkan hasil penelitian dan pembahasan dapat disimpulkan bahwa pembelajaran menggunakan strategi pembelajaran TSTS berbasis WhatsApp berpengaruh terhadap peningkatan hasil belajar siswa kelas, dengan demikian rata-rata hasil belajar siswa menggunakan pendekatan strategi pembelajaran TSTS berbasis WhatsApp lebih baik dari rata-rata hasil belajar menggunakan pendekatan konvensional.

\section{DAFTAR PUSTAKA}

Asriyanti, S., Ernawati, E., \& Rahim, R. A. (2020). Pengaruh Model Pembelajaran Cooperative Tipe Two Stay Two Stray (TSTS) dengan Media Whatsapp terhadap Prestasi Belajar 
Matematika Siswa Kelas VII SMP Negeri 1 Maros. Equals, 3(2), 63-70.

Febriyanti, E. A. W., Jampel, I. N., \& Syahruddin, S. P. (2014). Pengaruh Metode Pembelajaran Two Stay Two Stray Berbantuan Media Konkret Terhadap Hasil Belajar Siswa Kelas V. MIMBAR PGSD Undiksha, 2(1).

Hamruni. (2012). Strategi Pembelajaran. Yogyakarta: Insan Madani.

Hendrawan, K., Pudjawan, K., \& Wibawa, I. M. C. (2017). Pengaruh Model Pembelajaran Kooperatif Tipe Two Stay Two Stray (TSTS) Terhadap Hasil Belajar Siswa Kelas III di SD Gugus VIII Kecamatan Buleleng Tahun Pelajaran 2016/2017. MIMBAR PGSD Undiksha, 5(2), 1-10.

Lestari, L., Tangkas, I. M., \& Sabang, S. M. (2014). Pengaruh Model Pembelajaran Kooperatif Tipe Two Stay Two Stray Terhadap Hasil Belajar Siswa Kelas XI IPA Di SMA Negeri 2 Pasangkayu Pada Pokok Bahasan Bentuk Molekul. Jurnal Akademika Kimia, 3(1), 15-20.

Moro, H. K. E. P. (2016). Pengaruh Penggunaan WhatsApps Messenger Terhadap Prestasi Belajar Mahasiswa Kelas KKH di PBIO FKIP UAD. Universitas Ahmad Dahlan.

Sanjaya, W. (2012). Strategi Pembelajaran: Berorientasi Standar Proses Pendidikan. Jakarta: Kencana.

Sudjana, N. (2009). Penilaian Hasil Proses Belajar Mengajar. Bandung: PT Remaja Rosdakarya.

Wahyuni, I., \& Munthe, Y. G. (2014). Pengaruh Model Pembelajaran Kooperatif Tipe Two Stay Two Stray (TSTS) Terhadap Hasil Belajar Siswa pada Materi Listrik Dinamis pada Siswa SMA. Jurnal Pendidikan Fisika, 3(1), 1-7.

Wowor, E. C., Tumewu, W. A., \& Rogahang, M. K. (2020). Penyelesaian Tugas Kelompok Mahasiswa Melalui Google Document. JISIP (Jurnal Ilmu Sosial dan Pendidikan), 4(4), 320-324.

Zhafira, N. H., Ertika, Y., \& Chairiyaton, C. (2020). Persepsi mahasiswa terhadap perkuliahan daring sebagai sarana pembelajaran. Jurnal Bisnis
Dan Kajian Strategi Manajemen, 4(1), 37-45. 